\title{
TESTS AND SELECTION METHODOLOGY FOR BRAKE LININGS FRICTION MATERIAL
}

\author{
Pawel Grygorcewicz, Andrzej Tywoniuk \\ Institute of Aviation, Landing Gear Department \\ Krakowska Av. 110/114, 02-256 Warsaw, Poland \\ tel.: +48228460011 ext. 657, 219 \\ e-mail: pawel.grygorcewicz@ilot.edu.pl,andrzej.tywoniuk@ilot.edu.pl
}

\begin{abstract}
This article presents selected issues related to the selection methodology of the brake linings during the research process. It is a very important issue due to effect on the vehicle safety. Safety concerns are applicable to both road/track vehicles and aircraft. Scientific institutions and research centers make continuous efforts in order to improve brake lining materials and full-scale brakes. Analytical prediction of the friction material properties and behavior is not accurate enough due to complexity of the physical phenomena. Analysis of the friction materials is difficult due to scarce of data given by the manufacturers.

Every friction material needs to be tested in order to prove its properties. First stage of the selection is the tests made in laboratory using both model and full-scale techniques. Because of the laboratory tests, following parameters are obtained: weight and geometrical brake wear, braking torque, friction coefficient and brake temperature. All of these factors must be taken into account for linings selection and design a prototype of the brake. Selection of the friction material can be performed in consideration of various requirements of the brake system users and law defined factors. Authors of the paper base on the extensive experience of the Institute of Aviation, Landing Gear Laboratory tests of brake linings.
\end{abstract}

Keywords: transport, brakes, brake linings, friction material, laboratory tests

\section{Introduction}

The article describes the selection methodology of brake linings for new prototype of brake, which nowadays is the most important issue due to its effect on the vehicle safety. The aim the methodology is to check properties of the friction materials by performing series of laboratory tests. Afterwards, the linings could be used in new brake design. There are many types of brake linings materials on the market which can be used in designing process of the new prototype of brake.

The full process of braking is a complex phenomenon. Deceleration involves the change of the kinetic and potential energy of a vehicle into thermal energy. Brake design engineer must consider important factors including braking stability, brake force distribution, tire/road friction, level of brake utilization, braking while turning, pedal force modulation, stopping distance and brake wear (3). This article focuses on braking process tests. Chapters below show laboratory tests which led to select brake linings for improved brake system for heavy transport car.

\section{Test of the friction material in Landing Gear Laboratory}

First step of the laboratory tests is to create small samples from the friction material which will be tested. The tests are performed on the IL-68 test stand in Landing Gear Laboratory according to the test program and to the proper instruction manual. The test stand is designed to perform dynamic tests of brake friction materials without any interference from actual brake design. These tests give knowledge of general material behaviour in defined work conditions. It is also possible to perform direct comparison between different tests due to optimal repeatability (2). The tests are made on preselected materials - friction pair: brake pads lining and material for brake disc. First for each type of material, the researcher performs several braking for proper lining alignment followed by ten trial brakings. 


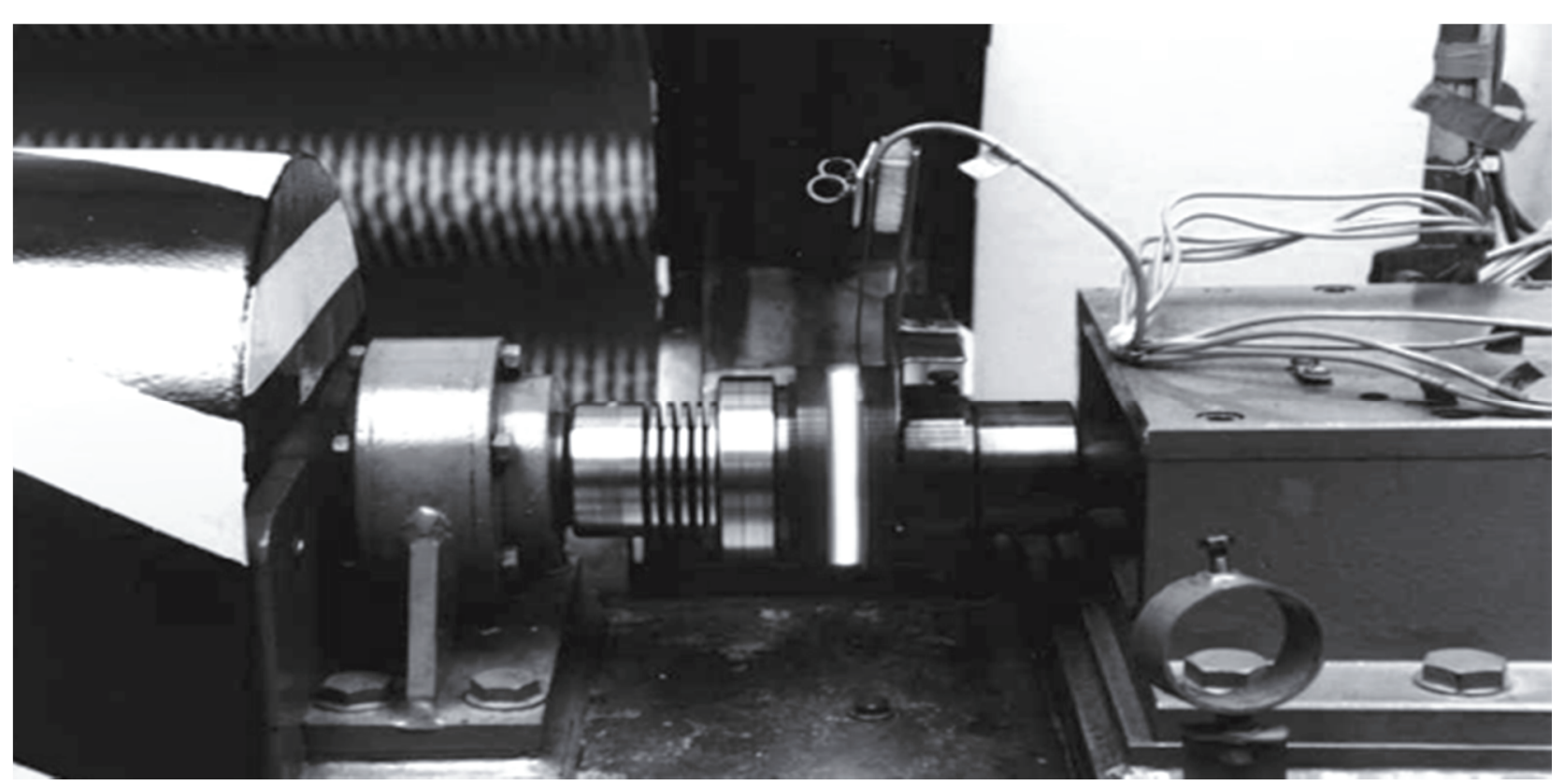

Fig. 1. Machine IL-68 in Landing Gear Laboratory

Tab. 1. Il-68 Technical Data

\begin{tabular}{|c|l|l|}
\hline \multicolumn{2}{|c|}{ IL68 TECHNICAL DATA } \\
\hline $\mathbf{N}^{\mathbf{0}}$ & Parameter name & Parameter value \\
\hline 1. & Maximal drive shaft rotation velocity & $9000 \mathrm{rpm}$ \\
\hline 2. & Torque & $0.154-1.54 \mathrm{~kg} \mathrm{x} \mathrm{m}^{2}$ \\
\hline 3. & Maximal loads on the sample surface & $5.88 \mathrm{kN}$ \\
\hline
\end{tabular}

In order to understand the IL-68 test procedure one has to know its operating principle. IL-68 test stand is equipped with two test heads: the rotary head and the stationary head (Fig. 1.). At the beginning of the test the rotating head achieves the specific speed. Then the stationary head is pressed to the rotary head. Fig. 1 shows the IL-68 test stand during brake material dynamic test process (visible light and glow in the middle is from test samples).

The braking process takes $15-20 \mathrm{sec}$. IL-68 test stand can record number of parameters such as: braking force, braking torque and test sample temperature(s). The full test lasts about few minutes. Before next one the heads (i.e. friction material) have to be cooled before performing next test. Every test should be done in the same conditions. It is very important due to possibility to compare the results after performing full test procedure.

Friction material is divided into eight special samples which are mounted in the rotary head. The disk material is mounted in the stationary head. The samples used in IL-68 machine heads are shown below (Fig. 2). Due to research process specifics test samples are often made out of commercial available materials. Shape of the samples is obtained by cutting it out from ready to go brake pads (Fig. 3).

During the tests the temperature reaches typically range between $400-600^{\circ} \mathrm{C}$ (up to $1000^{\circ} \mathrm{C}$ for $\mathrm{C}-\mathrm{C}$ composites). The colour of the friction material depend on temperature and can be red, light yellow or white what can be seen in the Fig. 1.

As it was mentioned earlier brake linings selection trial consists of two stages. First one is made in order to achieve proper lining alignment (break-in). Brake-in lining test is approved if three successive brakings have stable braking torque (Tab. 2 - grey rows). 

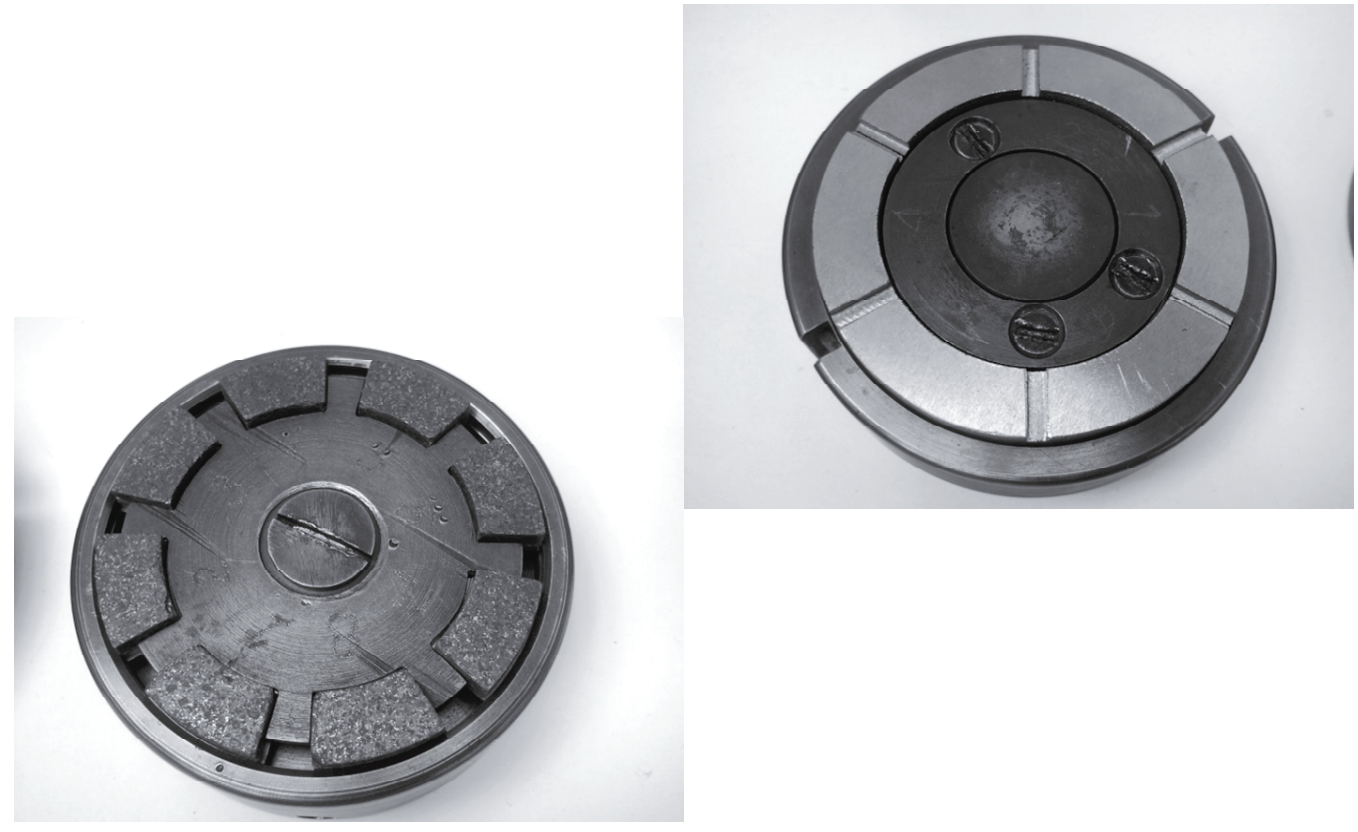

Fig. 2. Special samples of the friction materials, which are used in tests

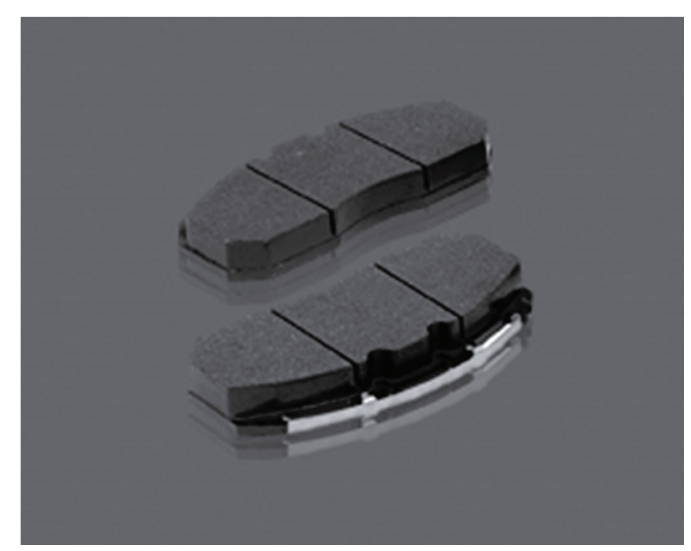

Fig. 3. Brake pads (7)

Tab. 2. Factors of the materials from break-in tests

\begin{tabular}{|c|c|c|c|c|c|c|c|c|}
\hline $\mathbf{N}^{0}$ & $\begin{array}{c}\mathrm{M}_{\mathrm{D}}(\mathrm{t}) \\
\mathrm{sr}\end{array}$ & $\begin{array}{c}\mathrm{M}_{\mathrm{D}}(\mathrm{t}) \\
\max \end{array}$ & $P_{S r}(t)$ & $\mathrm{p}_{\text {JSr }}$ & $\begin{array}{l}\mu_{\mathrm{D}} \\
\mathrm{sr}\end{array}$ & $\begin{array}{l}\mu_{\mathrm{D}} \\
\max \end{array}$ & $\alpha$ & $t_{H}$ \\
\hline - & $\mathrm{daNcm}$ & daNcm & daN & $\mathrm{daNcm}^{2}$ & - & - & - & $\mathrm{s}$ \\
\hline 1 & 101.36 & 145.97 & 86.59 & 6.1 & 0.361 & 0.519 & 0.69 & 22.4 \\
\hline 2 & 98.98 & 145.32 & 85.81 & 6.04 & 0.355 & 0.522 & 0.68 & 23 \\
\hline 3 & 101.8 & 153.55 & 86.19 & 6.07 & 0.364 & 0.549 & 0.66 & 22.4 \\
\hline 4 & 99.22 & 152.9 & 85.72 & 6.04 & 0.357 & 0.549 & 0.65 & 23 \\
\hline 5 & 102.75 & 151.39 & 85.26 & 6 & 0.371 & 0.547 & 0.68 & 22.3 \\
\hline 6 & 104.49 & 145.75 & 86.24 & 6.07 & 0.373 & 0.521 & 0.72 & 21.9 \\
\hline 7 & 103.67 & 150.52 & 86.16 & 6.07 & 0.371 & 0.538 & 0.69 & 22.1 \\
\hline 8 & 104.8 & 149.87 & 85.61 & 6.03 & 0.377 & 0.539 & 0.7 & 21.9 \\
\hline 9 & 103.6 & 148.57 & 84.23 & 5.93 & 0.379 & 0.543 & 0.7 & 22.2 \\
\hline 10 & 103.06 & 147.92 & 85 & 5.99 & 0.373 & 0.536 & 0.7 & 22.3 \\
\hline
\end{tabular}

Table 2 - parameters: $\mu_{D}$ - friction coefficient max and average, $M_{D}$ - max and average braking torque, $P_{S r}-$ average downforce, $p_{J S}$ - average downforce per unit area, $t_{H}$-braking time, $\alpha$-factor of stability friction coefficient. These parameters are taken into account in laboratory tests. 
Second stage of IL-68 trial made after break-in tests are the ten brakings made in order to determine physical properties of the friction material. Results of the tests are presented in form of graphs (Fig. 4) as well as tabulated set of parameters (Tab. 3-5).

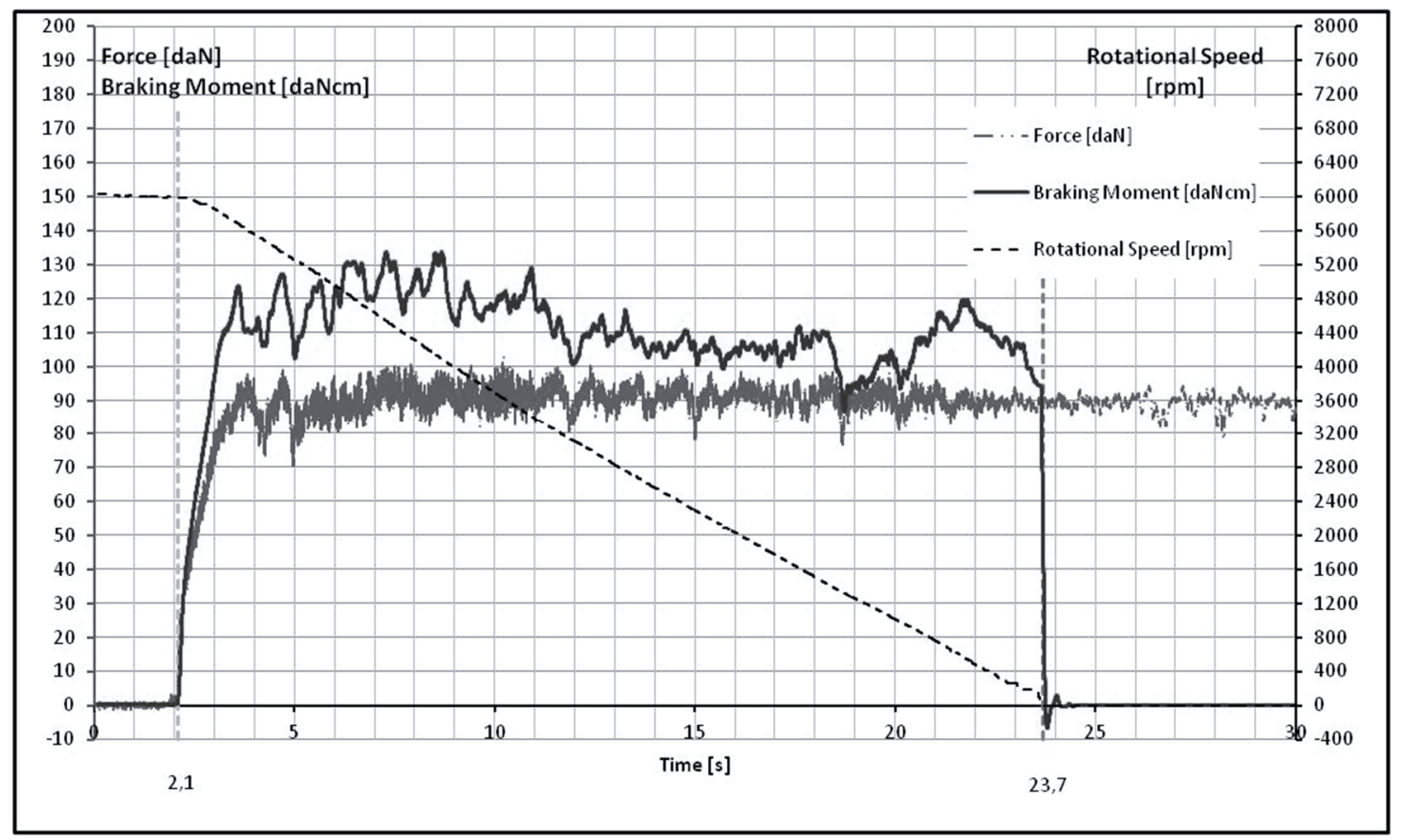

Fig. 4. Model (friction material) test - IL 68 Test Stand [2]

Tab. 3. Factors of the materials from tests

\begin{tabular}{|c|c|c|c|}
\hline Measurement & $\mathrm{M}_{\mathrm{S}}$ & $\mathrm{P}$ & $\mu_{\mathrm{S}}$ \\
\hline- & $\mathrm{daNcm}$ & $\mathrm{daN}$ & - \\
\hline After 5 braking & 52.46 & 87.03 & 0.186 \\
\hline After 6 braking & 57.76 & 90.68 & 0.196 \\
\hline
\end{tabular}

Table 3 - parameters: $\mu_{s}$ - friction coefficient, $M_{s}$-static torque, $P$ - downforce.

One of the very important parameter defining friction pair material is the wear of the lining. In Landing Gear Department laboratory there are two methods of the linings wear estimation. In the first method the linear wear (Tab. 4) is measured and in the second one the weight of the sample is measured (Tab. 5).

Every sample is checked for debris, cracks or chippings.

Tab. 4. Thickness of the samples after tests

\begin{tabular}{|l|c|c|c|c|c|c|}
\hline \multirow{2}{*}{$\begin{array}{c}\text { Thickness of samples } \\
\text { [mm] }\end{array}$} & \multicolumn{7}{|c|}{ Number of the sample } \\
\cline { 2 - 7 } & I & II & III & IV & V & VI \\
\hline Before 10th braking & 7.01 & 6.97 & 6.98 & 7.00 & 6.98 & 6.98 \\
\hline After 10th braking & 6.98 & 6.93 & 6.975 & 6.98 & 6.98 & 6.97 \\
\hline Wear [mm] & 0.03 & 0.04 & 0.005 & 0.02 & 0.01 & 0.01 \\
\hline
\end{tabular}

Tab. 5. Mass of the samples after tests

\begin{tabular}{|l|c|c|}
\hline & samp. & samp. \\
Measurement of the mass [g] & $21-23$ & $24-26$ \\
\hline Before 10th braking & 49.081 & 49.814 \\
\hline After 10th braking & 48.656 & 49.509 \\
\hline Wear [g] & 0.425 & 0.305 \\
\hline
\end{tabular}


Next step in the methodology is full scale brake test. The results from the IL-68 test stand are compared and the best material is selected to be tested on Młot-3T test stand (Fig. 5, Tab. 6.) located in Institute of Aviation Landing Gear Laboratory, which imitates the real braking conditions. These tests give knowledge of performance and behaviour in order to improve full scale brake design. Młot $3 \mathrm{~T}$ tests are required to evaluate brake design and to prove its efficiency and reliability (2). Test stand allow the researcher to change test parameters in order to evaluate behaviour of the brake.

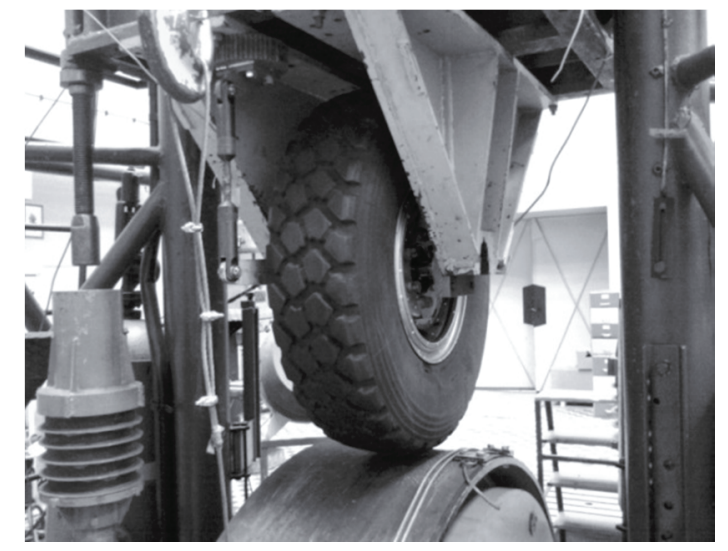

Fig. 5. Mtot 3T test stand with brake and wheel mounted during tests (source: ILot)

Tab. 6. Młot 3 T Technical Data

\begin{tabular}{|l|l|l|}
\hline \multicolumn{2}{|c|}{ MLOT 3T TECHNICAL DATA } \\
\hline $\mathbf{N}^{\mathbf{0}}$ & Parameter name & Parameter value \\
\hline 1. & Maximal weight of tested object including mounting parts & $3 \mathrm{~T}$ \\
\hline 2. & Maximal vertical force during the tests & $118 \mathrm{kN}$ \\
\hline 3. & Maximal buffer pressure & $1.96 \mathrm{MPa}$ \\
\hline 4. & Drum maximal rotational speed & $800 \mathrm{rpm}$ \\
\hline 5. & Drum maximal peripheral speed & $211 \mathrm{~km} / \mathrm{h}(58.6 \mathrm{~m} / \mathrm{s})$ \\
\hline 6. & Drum exterior diameter & $1400 \mathrm{~mm}$ \\
\hline 7. & Drum width & $530 \mathrm{~mm}$ \\
\hline 8. & Buffer force & $0-22.2 \mathrm{kN}$ \\
\hline
\end{tabular}

Presented test stand can record number of parameters such as: braking moment, braking force, speed, temperature and hydraulic pressure.

Results of the tests are presented in form of graphs (Fig. 6).

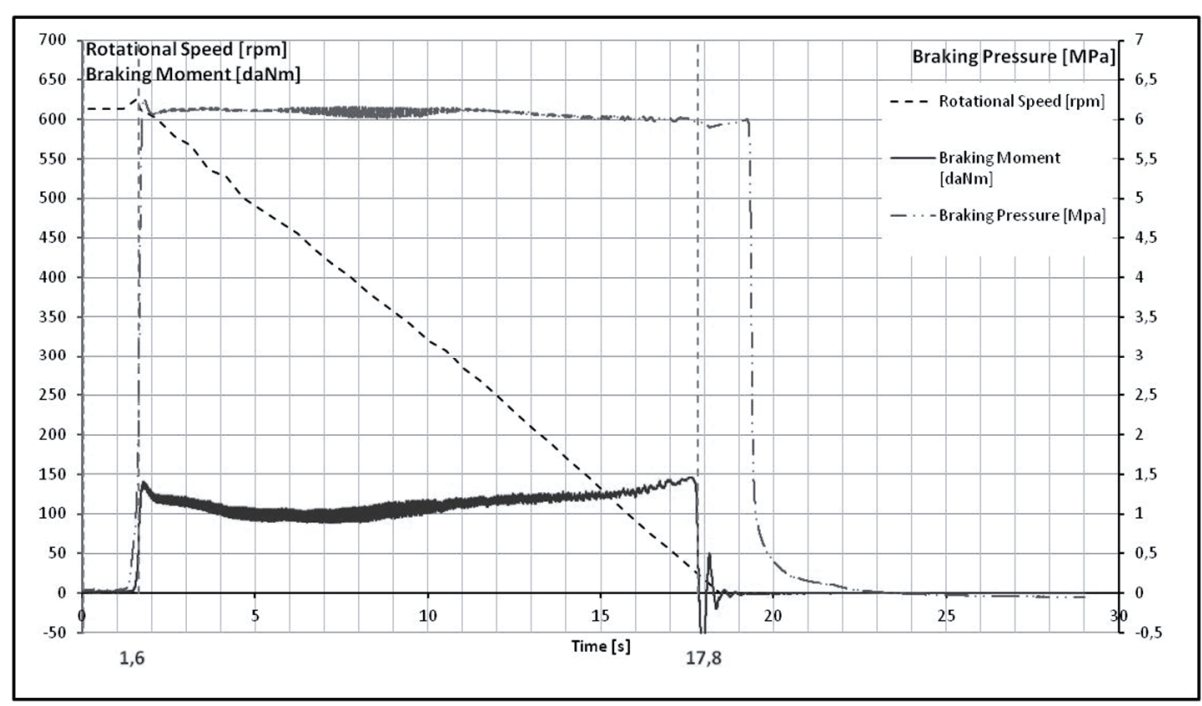

Fig. 6. Full-scale test of the brake-Młot 3 T Test Stand (2) 


\section{The results}

Nowadays the lining composition is classified by the manufacturer so the laboratory bases on parameters which can be obtained from the tests (ex. curves of the coefficient of friction as a function of load and of the speed differential between the lining and facings and their mating surface (4)). As a result of the tests data was obtained in the following table.

Tab. 7. The values obtained in testsIL68

\begin{tabular}{|c|c|c|c|c|}
\hline \multirow{2}{*}{ Parameter } & \multicolumn{4}{|c|}{ The value obtained in tests } \\
\cline { 2 - 5 } & Material 1 & Material 2 & Material 3 & Material 4 \\
\hline$\mu_{\mathrm{D}}$ & 0.386 & 0.40 & 0.38 & 0.36 \\
\hline$\alpha$ & 0.788 & 0.71 & 0.68 & 0.765 \\
\hline $\mathrm{Z}_{\mathrm{mw}} /$ 1-braking. & 26.6 & 21.67 & 15.15 & 91.7 \\
\hline $\mathrm{Z}_{\mathrm{dw}} / 1$-braking & 1.75 & 0.75 & 1.38 & 4.38 \\
\hline
\end{tabular}

Table 7 - parameters: $\mu_{D}$ - friction coefficient, $\alpha$ - factor of stability friction coefficient, $Z_{m w}$ - the wear of lining material per one braking, $Z_{d w}$ - the wear of the brake disc material.

As it can be seen in exemplary results table (Tab. 7) four materials were tested. Based on the results, the materials number 2 and 3 were selected for further consideration because material 1 and 4 had to high wear of the lining (what was the most important factor in these trials) and not suitable friction coefficient.

Selected pairs of friction were characterized by low wear while the linear coefficient of friction was stable in wide range of temperatures. In this case selected friction pairs could be used in brake. Afterwards, the complete brake with linings made out of material 2 were tested on the Młot $3 \mathrm{~T}$ test stand (results Tab. 8).

Tab. 8. The results obtained in Mlot-3T tests

\begin{tabular}{|c|c|c|c|c|c|c|c|c|}
\hline $\mathrm{N}^{0}$ & $\mathrm{~N}^{\circ}$ of the file & $\mathrm{p}_{\mathrm{n}}$ & $\mathrm{p}_{\mathrm{h}}$ & $\mathrm{M}_{\mathrm{S}}$ & $\mathrm{M}_{\mathrm{hmax}}$ & $\mathrm{t}_{\mathrm{h}}$ & $\mathrm{V}_{\mathrm{b}}$ & $\mathrm{n}_{\mathrm{ob}}$ \\
\hline- & - & {$[\mathrm{MPa}]$} & {$[\mathrm{MPa}]$} & {$[\mathrm{Nm}]$} & {$[\mathrm{Nm}]$} & {$[\mathrm{s}]$} & {$[\mathrm{km} / \mathrm{h}]$} & {$[\mathrm{rpm}]$} \\
\hline 1 & dhtt_0011 & 6 & 6.11 & 1251 & 1459 & 6.2 & 60 & 228 \\
\hline 2 & dhtt_0012 & 6 & 6.09 & 1280 & 1338 & 5.9 & 60 & 228 \\
\hline 3 & dhtt_0013 & 6 & 6.12 & 1305 & 1364 & 5.9 & 60 & 228 \\
\hline 4 & dhtt00014 & 6 & 6.15 & 1385 & 1448 & 5.7 & 60 & 228 \\
\hline 5 & dhtt_0015 & 6 & 6.05 & 1399 & 1459 & 5.7 & 60 & 228 \\
\hline 7 & dhtt_0016 & 8 & 7.87 & 1852 & 1937 & 4.3 & 60 & 228 \\
\hline 8 & dhtt0017 & 8 & 8.01 & 1914 & 2013 & 4.5 & 60 & 228 \\
\hline 9 & dhtt_0018 & 8 & 8.04 & 1921 & 2028 & 4.2 & 60 & 228 \\
\hline 10 & dhtt0019 & 8 & 7.98 & 1926 & 2035 & 4.1 & 60 & 228 \\
\hline 11 & dhtt_0020 & 8 & 7.97 & 1945 & 2048 & 4.1 & 60 & 228 \\
\hline 12 & dhtt_0021 & 8 & 8.03 & 1996 & 2122 & 6.6 & 100 & 380 \\
\hline 13 & dhtt_0022 & 8 & 8.17 & 2318 & 2531 & 5.8 & 100 & 380 \\
\hline 14 & dhtt0023 & 8 & 8.10 & 2389 & 2634 & 5.6 & 100 & 380 \\
\hline
\end{tabular}

Table 8 - parameters: $p_{n}$ - pressure, $p_{h}$ - braking pressure, $M_{S}$ - static torque, Mhmax - dynamic torque, $t_{H}-b_{r a k i n g}$ time, $V_{b}$-drum linear velocity, $n_{o b}-d r u m$ rotational velocity.

\section{Conclusions}

As it was described above, proper selection methodology of brake friction material needs to be done experimentally by laboratory testing. Analytical prediction of the friction material properties and behaviour is not accurate enough due to complexity of the physical phenomena. 
Tests are done in two stages model and full scale. Model testing (IL-68) is necessary to determine the parameters and physical properties of the friction material without any interference form actual brake design. Full scale testing (Młot 3T) follows model tests in order to determine material behaviour in brake itself.

Proper material selection is crucial because it is strictly connected with braking distance and with the vehicle operation safety. It is very important to do the tests strictly following proper instructions. These kind of tests are made at Institute of Aviation Landing Gear Laboratory where scientists and engineers make them on daily basis.

\section{References}

[1] Grygorcewicz, P., Skorupka, Z., The laboratory tests friction brakes in Landing gear department, TTS, 2013.

[2] Skorupka, Z., Braking moment comparison and analysis for various brake design using results from sample and full scale friction material tests, Journal of KONES Powertrain and Transport., Vol. 1, pp. 303-308, 2013.

[3] Limpert, R., Brake design and safety, Society of Automotive Engineers, 1999.

[4] Orthwein, W. C., Clutches and Brakes Design and Selection, Mercel Dekker, 2004.

[5] Reński, A., Budowa samochodów Układy hamulcowe i kierownicze, Warsaw University of Technology Publishing House, 2004.

[6] Institute of Aviation Landing Gear Report, of Aviation Landing Gear Report, Laboratory tests of armored cars brake lining sectors with thermovision made with IL-68 test rig, 26/LW/2009, Institute of Aviation, 2009.

[7] http://www.qap-auto.com/pl/oferta. 